\title{
The Wilhelmøya Formation (Upper Triassic-Lower Jurassic) at Bohemanflya, Spitsbergen
}

\author{
HENNING DYPVIK, SVEN HVOSLEF, TOR BJÆRKE AND EGIL FINNERUD
}

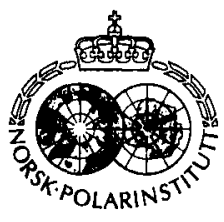

Dypvik, H., Hvoslef, S., Bjarke, T. \& Finnerud, E. 1985: The Wilhelmøya Formation (Upper TriassicLower Jurassic) at Bohemanflya, Spitsbergen. Polar Research 3 n.s., 155-165.

An $18.5 \mathrm{~m}$ thick shale sequence of Norian-Rhaetian age is described from the Bohemanflya-Syltoppen area (north of Isfjorden. central Spitsbergen). Lithological, petrographical and palynological analyses show that the sequence represents a marginal development of the lower part of the Wilhelmøya Formation. The depositional history at the Triassic-Jurassic transition is discussed in the light of this new evidence. The Wilhelmøya Formation was probably deposited during a weak marine transgression over an area of low relief. Low sediment supply and current and wave reworking of the sediments characterized the depositional conditions.

Henning Dypuik and Suen Huoslef, Department of Geology, University of Oslo, P.O. Box 1047, Blindern. Oslo 3, Norway; Tor Bjarke, Stratlab, 3290 Stavern. Norway; Egil Finnerud, Norsk Hydro, P.O. Box 490. 1301 Sandvika, Norway; June 1984 (revised May 1985).

The sedimentary development across the Triassic-Jurassic boundary in Svalbard was previously regarded as a late Triassic regressive development followed by a regional phase of uplift and period of non-deposition, lasting until the Toarcian (Buchan et al. 1965). Sediments of Toarcian age were known to be represented only as reworked concretions in the Brentskardhaugen Bed, which was formed before or at the start of the transgression which resulted in deposition of the late Bathonian to Volgian age shales of the Agardhfjellet Member.

The recognition of sediments of Lower Jurassic age in eastern Svalbard at Wilhelmøya, Hellwaldfjellet, Hopen and Kong Karls Land (Klubov 1965; Pcelina 1980; Worsley 1973; Worsley \& Heintz 1977; Smith et al. 1975) was the first evidence of a much more complex depositional history during this time interval. Worsley (1973) established the Wilhelmøya Formation to cover these sediments. Bjærke \& Dypvik (1977) described a $15 \mathrm{~m}$ thick sequence in Sassenfjorden central Spitsbergen, representing a condensed and incomplete development of the Wilhelmøya Formation. Later the Wilhelmøya Formation or equivalents to this unit have been described from several other localities in Spitsbergen by Bäckstrøm (1980), Knarud (1980), and Mørk et al. (1982) (Fig. 1).

The present paper describes a section through the Wilhelmøya Formation north of Isfjorden, at
Bohemanflya. This study was designed to provide stratigraphical and sedimentological information from the north-westernmost localities of the Wilhelmøya Formation.

\section{Field description}

In the Bohemanflya-Syltoppen area, well-developed exposures of the De Geerdalen, Wilhelmøya and Janusfjellet formations were found in a minor canyon on the eastern slope of Syltoppen (Fig. 1). Here, as in the equivalent section both on Festningen and Selmaneset in the outer Isfjorden area, the De Geerdalen Formation consists of grey sandstones and red, grey and green shales together with carbonate cemented sand and siltstone beds (Fig. 2). The uppermost ten metres of the De Geerdalen Formation are made up of a $6 \mathrm{~m}$ thick coarsening upwards sequence, which ends in a homogeneous sandstone unit.

The Wilhelmøya Formation is $18.5 \mathrm{~m}$ thick in this area. The uppermost boundary towards the Janusfjellet Formation is marked by the Brentskardhaugen Bed. The lower boundary of the formation is more difficult to determine in the field, but is probably defined by an erosional episode observed in the sandstones about $10 \mathrm{~m}$ above the base of the section (Fig. 2). In the Sassenfjorden and Isfjorden area this boundary is marked by a phosphate conglomerate. 


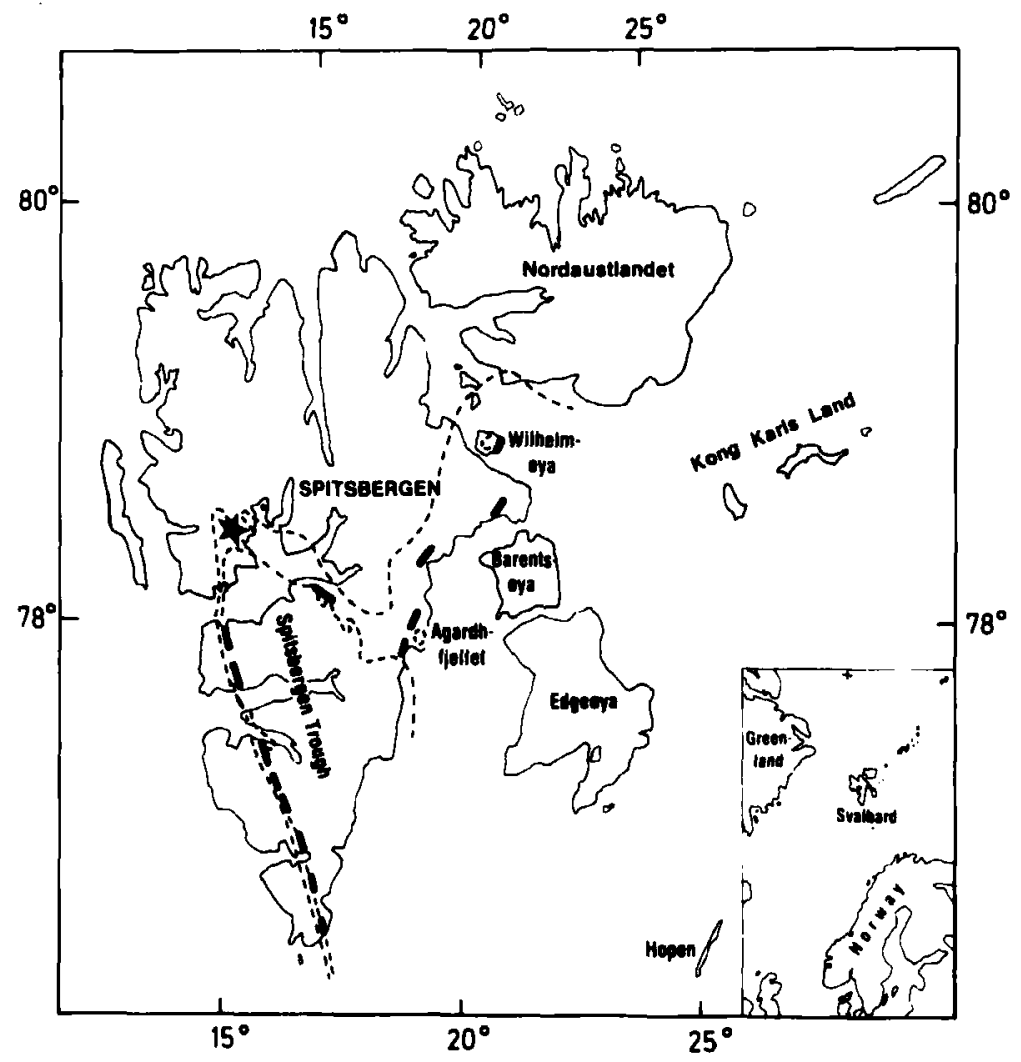

Fig. 1. Localities where the Wilhelmøya Formation and equivalent sediments have been found in Svalbard.
The sandstone contains in the lower part ripple lamination and steep angle cross bedding, while the overlying beds of the Wilhelmøya Formation are made up of silty shales with frequent carbonate beds with cone-in-cone structures. Eighteen metres above the base of the section (Fig. 2) there is a coarsening upwards unit of carbonate cemented silty/sand beds which is laminated and bioturbated in the upper part. Above this horizon again grey shales and carbonate layers with conein-cone and pisolittic structures are found.

The three metres of sediments deposited above the cemented silt/sandstone consist of carbonate cemented shales with additional lenses of carbonate $(0.1$ to $0.5 \mathrm{~m}$ in diam.). This is followed by $0.5 \mathrm{~m}$ of bioturbated silty shales, which are again overlain by carbonate cemented silty shales. Above these units a $0.7 \mathrm{~m}$ thick development of the Brentskardhaugen Bed is found. The conglomerate contains in this area oblate to prolate, well-rounded pebbles of different lithological composition and $0.5-3 \mathrm{~cm}$ in size.

The Brentskardhaugen Bed contains only rela- tively small and scattered phosphate pebbles in contrast to the abundant phosphatic clasts found in other areas (Agardhbukta, Wimanfjellet, Janusfjellet, Festningen, van Keulenfjorden) (localities shown in Fig. 1).

The Brentskardhaugen Bed is overlain by $3 \mathrm{~m}$ of silty shales belonging to the Agardhfjellet Member, Janusfjellet Formation. A $30 \mathrm{~m}$ thick, homogeneous, organic-rich bioturbated sandstone unit follows above this shale sequence.

\section{Sediment composition}

\section{Petrography}

The petrographical description is based on field observations, thin section analyses, and X-ray diffraction determinations.

The sandstones of the De Geerdalen Formation show various degrees of sorting. Quartz, mica and altered feldspar dominate, but the feldspar may be heavily altered to illite and aggregates of illite/ 


\section{THE BOHEMANFLYA/SYLTOPPEN SECTION}

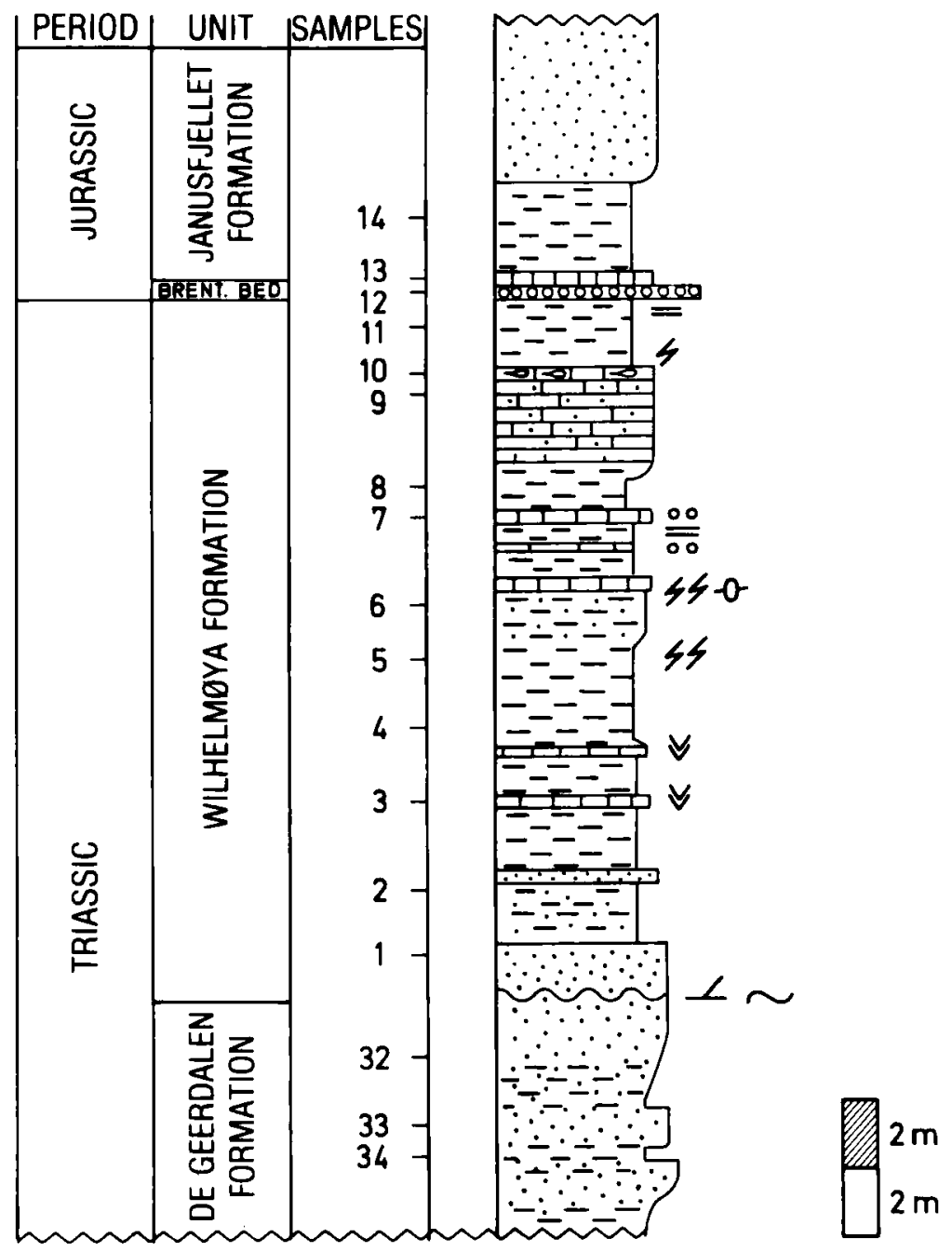

Fig. 2. Sedimentological log of the Wilhelmøya Formation at Bohemanflya/Syltoppen, Spitsbergen. Metre scale to the right.

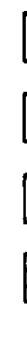

$\because \because 8$ Conglomerate
$\because \because$ Sandstone
$\square--$ Silty shale

臣 Carbonate $\angle$ Crossbedding

$\sim$ Ripple lamination

$=$ Parallell lamination

- Trace fossils

$\zeta$ Bioturbation

$\Downarrow$ Cone-in-cone

- Pisolites 

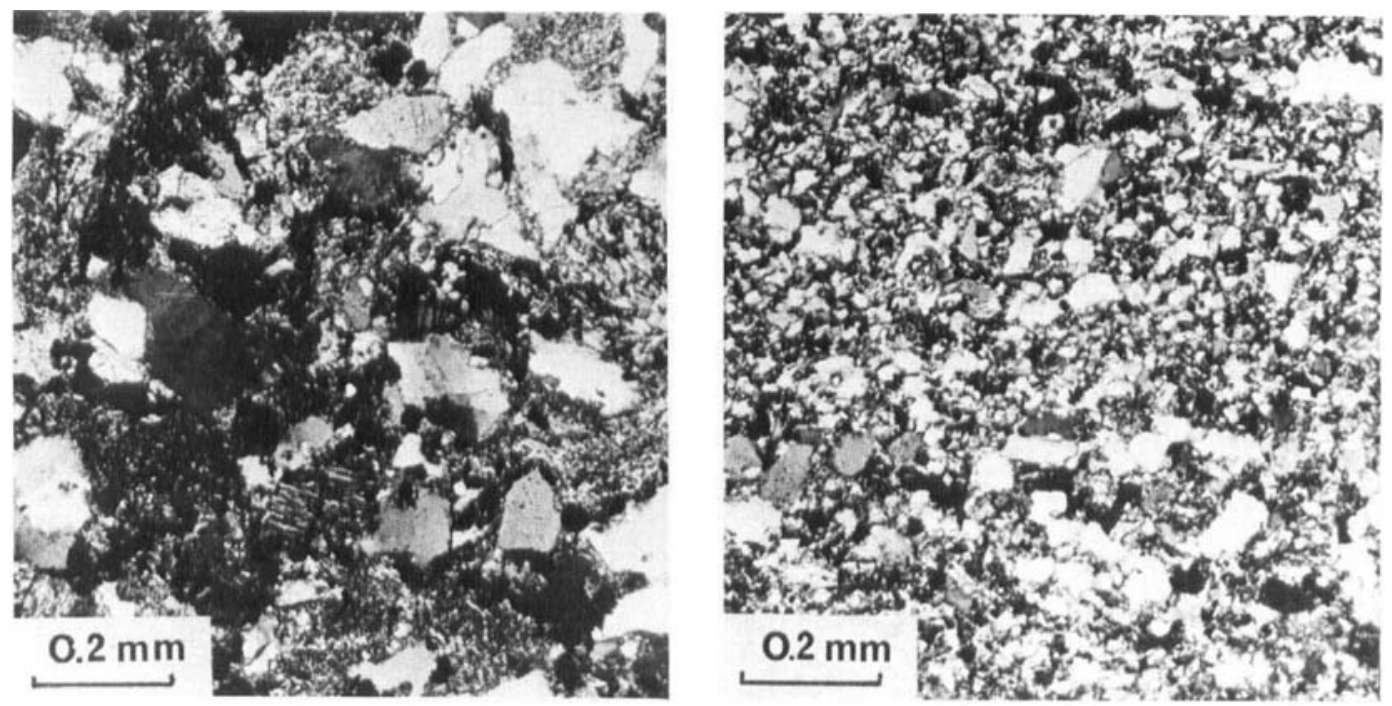

Fig. 3. Micrographs of samples from the De Geerdalen Formation (left) and the Wilhelmøya Formation (right). The photos are taken under X-nicols.

smectite mixed layered clay minerals. In addition, dispersed organic material is frequent, as well as phosphate fragments. Minor amounts of glauconite, chlorite, pyrite and chert have also been observed.

The samples from the Wilhelmøya Formation (Fig. 3) show a somewhat higher quartz content than the samples from the De Geerdalen Formation (Table 1). The samples from the De Geerdalen Formation are, however, generally richer in feldspar, iron oxides and siderite compared to the Wilhelmøya Formation samples (Fig. 3, Table 1) (cp. Bjærke \& Dypvik 1977). Poor sorting and a predominantly illitic matrix are also typical of these samples, the matrix resembling the illitized feldspar of the De Geerdalen Formation (Fig. 3). Quartz cementation has not been observed so far.

The Brentskardhaugen Bed sample consists of phosphate cemented clastic grains of rock fragments, quartz and chert. Part of the conglomerate consists of siderite pisolites.

A more extensive discussion of the petrography of the Wilhelmøya and De Geerdalen Formations is found in Mørk et al. (1982).

\section{Organic components}

Analysis of organic content and composition was done both chemically and visually. Total organic carbon (TOC) and Rock Eval analyses (Espitalié 1977) were carried out on crushed whole rock samples, while optical kerogen analyses were achieved on strew mounts of screened and unscreened residues after $\mathrm{HCl}, \mathrm{HF}$ and heavy liquid separation (Finnerud 1982). The samples contain from 0.3 to $1.2 \%$ TOC, and Rock Eval analyses gave hydrogen indices $(\mathrm{HI})$ between 21

Table 1. Petrographical composition of four thin sections studied. The amounts of quartz, rock fragments, mica, carbonates and iron oxides have been determined in \%.

\begin{tabular}{lllllll}
\hline Unit & Sample & \% Quartz & \% Rock frag. & \% Mica & \% Carb. & \% Fe-oxides \\
\hline Wilhelmøya & 1 sandstone & 41 & 53 & 5 & - & 1 \\
Formation & 5 siltstones & 42 & 51 & 15 & 1 & 1 \\
De Geerdalen & 10 sandstones & 44 & 53 & - & 2 & 1 \\
Formation & 37 sandstones & 38 & 49 & - & - & 13 \\
\hline
\end{tabular}




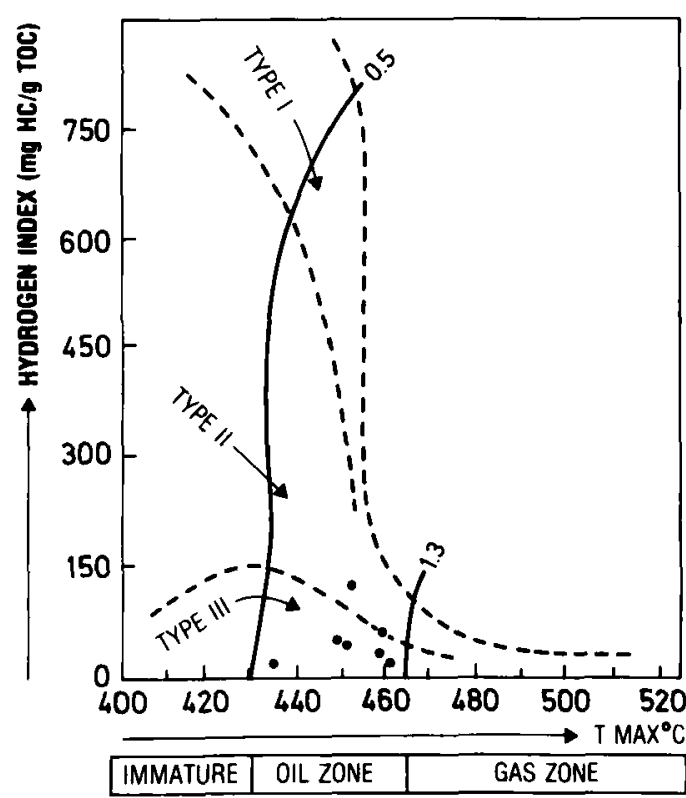

Fig. 4. Hydrogen index $-T_{\max }$ plot of seven Rock Eval analyses of samples from the Wilhelmøya Formation (Table 2). The kerogen types I, II and III (dashed line) are indicated as well as Ro values (whole line).

and $128 \mathrm{mg} \mathrm{HC} / \mathrm{g}$ org. $C$. The $\mathrm{T}_{\max }$ has an average of $452^{\circ} \mathrm{C}$, corresponding to vitrinite reflectance of about $1.0 \%$, typical for the catagenetic stage (Tissot \& Welte 1978).

Plots of $\mathrm{T}_{\max } v$. HI (Fig. 4) indicate kerogen similar to type III or IV, which is generally regarded to be of terrestrial origin (Tissot \& Welte 1978).

Optical analysis shows that the assemblage studied from the uppermost De Geerdalen Formation is dominated by membranous material (Fig. 5). Fragmented membranous material also forms the bulk of the finely dispersed debris. Spores and pollen are common, but poorly preserved in this assemblage. Marine palynomorphs are absent, inertinite and wood are present in only small amounts.

Although there are considerable differences in kerogen composition in the samples studied from the Wilhelmøya Formation, they contrast from the assemblage of the De Geerdalen Formation. Inertinite is abundant to dominant in all assemblages (in agreement with the Rock Eval analyses) except in sample 7, which belongs to a carbonate layer. Here particulate kerogen components are nearly absent. This assemblage is dominated by yellow finely dispersed, partly coherent debris.

Wood fragments are rare to common, while membranous material is common in one assemblage from the lower part of the interval, otherwise absent or rare. Terrestrial palynomorphs are common to abundant in most samples, but absent from the lowermost sample 2 and sample 7 as mentioned above. Marine palynomorphs, represented by acritarchs only, are common in sample 6 and rare in the upper part of the interval. Finely dispersed debris vary considerably throughout the interval from rare to totally dominating (see Fig. 5).

The sample studied from the Brentskardhaugen Bed produced a kerogen assemblage completely different from those in the other intervals. It is dominated by well-defined clusters or aggregates with a granular appearance. Finely dispersed debris of the same origin dominate the unscreened residue, but poorly preserved wood fragments are also present (Fig. 5). This characteristic kerogen composition has been observed from this particular horizon at several localities in Svalbard.

The kerogen assemblages from the lower part of the Agardhfjellet Member also show considerable variations, but differ from underlying beds in the presence of degraded debris and dinoflagellate cysts. Wood fragments are also generally more common in these assemblages. Finely dispersed debris and inertinite are common to abundant. Membranous material, partly representing fragments of dinoflagellate cysts, is common throughout the interval. Spores and pollen are rare in the two lowermost assemblages, but show an increase in the upper two assemblages where they are common.

\section{Palynology}

Fourteen samples from the studied section covering the top of the De Geerdalen Formation, the Wilhelmøya Formation, the Brentskardhaugen Bed and the lower part of the Agardhfjellet Member were studied palynologically. The samples from the Agardhfjellet Member were studied to establish the contrast towards the underlying beds. Forty-one palynomorph species were recorded (Table 2). The distribution of the species is shown in Fig. 6. Three stratigraphically distinctive assemblages (1-3) were recognized.

Assemblage 1, represented by one sample from a shale intercalation near the top of the De Geer- 


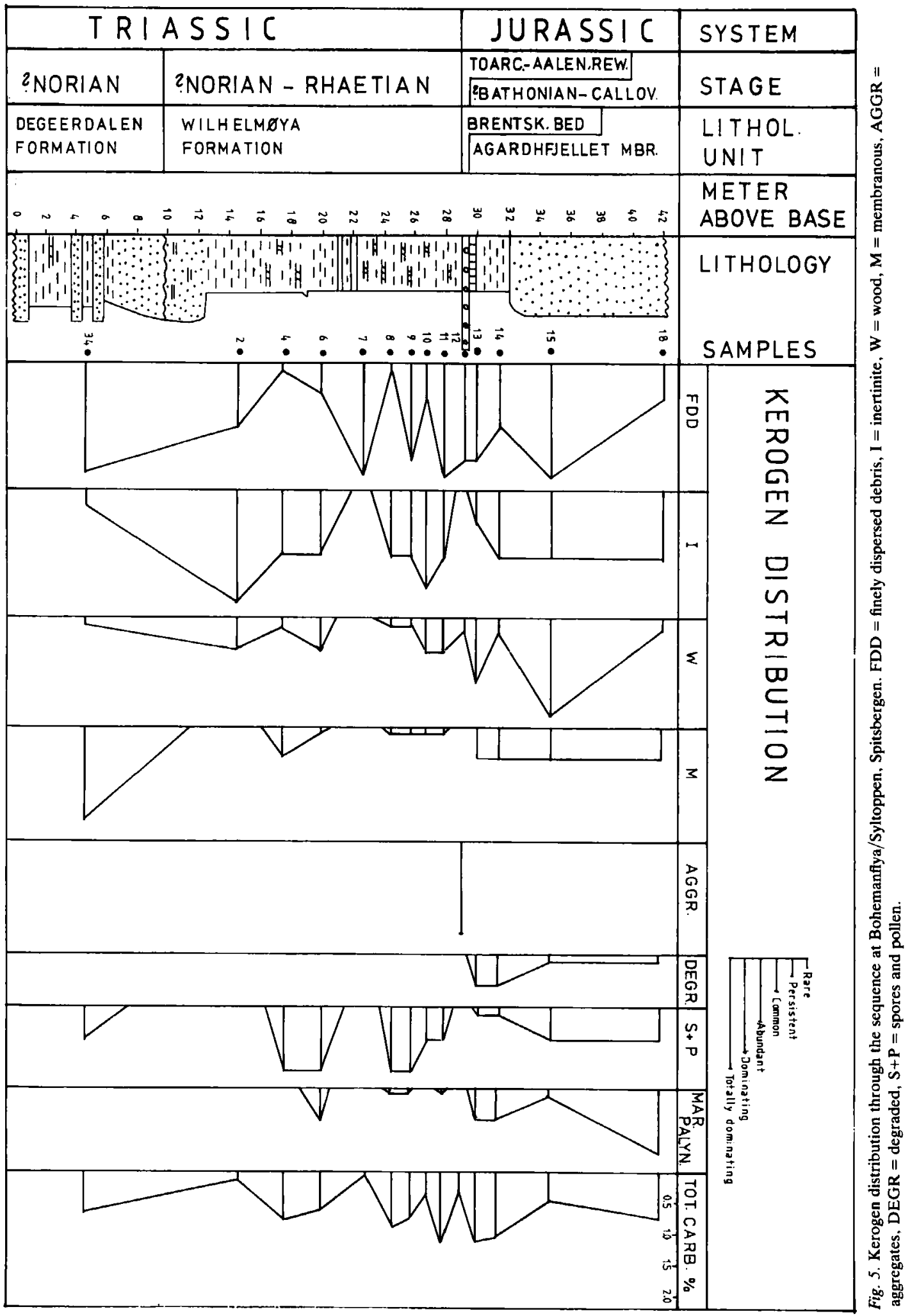




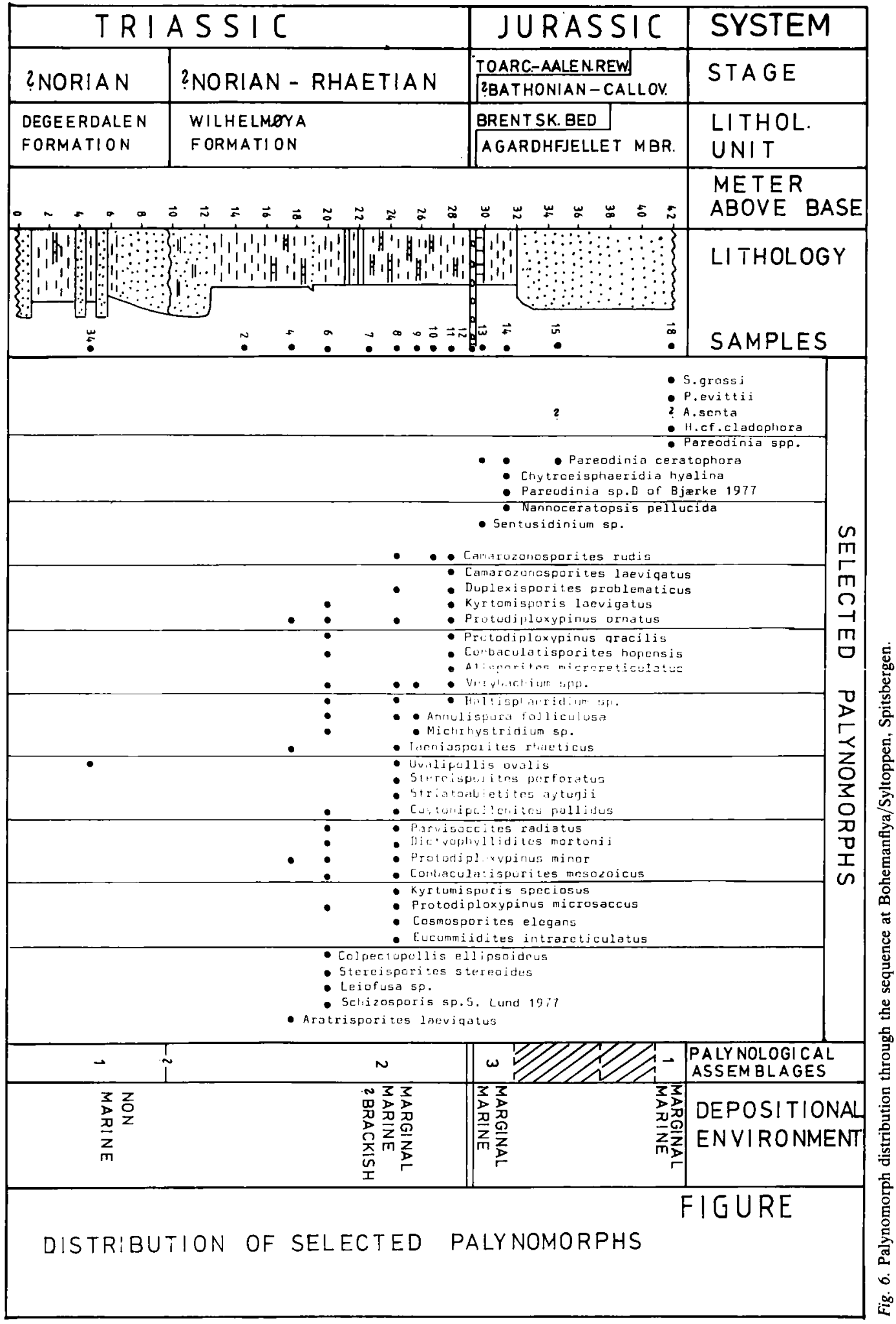


Table 2. Organic geochemical analyses of shale samples from the Wilhelmøya Formation and Agardhfjellet Member. Values for total organic carbon (TOC), $\mathrm{T}_{\max }$ in ${ }^{\circ} \mathrm{C}$ and the hydrogen index (HI) from Rock Eval pyrolysis are given.

\begin{tabular}{llll}
\hline Sample & $\begin{array}{l}\text { TOC \% } \\
\text { (by weight) }\end{array}$ & $\begin{array}{l}\mathrm{T}_{\max } \\
\left({ }^{\circ} \mathrm{C}\right)\end{array}$ & $\begin{array}{l}\text { HI } \\
\text { (mg HC/g org. C) }\end{array}$ \\
\hline 11 & 1.12 & 460 & 35 \\
9 & 0.37 & 458 & 67 \\
8 & 0.73 & 449 & 52 \\
7 & 0.88 & 461 & 18 \\
5 & 0.42 & 435 & 21 \\
4 & 0.77 & 451 & 48 \\
1 & 0.32 & 452 & 128 \\
\hline
\end{tabular}

dalen Formation, produced a poorly preserved assemblage in which only the species Ovalipollis ovalis could be identified. The kerogen assemblage is characterized by abundant wood and opaque debris and common, poorly preserved cuticle fragments.

Assemblage 2, covering the Wilhelmøya Formation, is characterized by large variations in palynomorph productivity. Of the eight samples studied from this interval, two were barren and three samples produced poor spore and pollen assemblages. In the upper part three samples produced relatively well-preserved and diverse spore and pollen assemblages.

Characteristic Upper Triassic elements such as Camarozonosporites rudis, $C$. laevigatus, Protodiploxypinus ornatus, P. minor, Annulispora folliculosa, Taeniasporites rhaeticus, and Kyrtomisporis speciosus were recorded. Aratrisporites laevigatus, Protodiploxypinus microsaccus, and Eucommiidites intrareticulatus, first described from the Wilhelmøya and De Geerdalen formations on Hopen, were recorded.

In addition to the spores and pollen, acritarchs belonging to the genera Baltispaeridium, Micrhystridium and Veryhachium are also present.

The only sample studied from the Brentskardhaugen Bed proved barren. The residue contained spherical structureless bodies.

Assemblage 3 is represented by two samples, one from the pisolittic bed just above the Brentskardhaugen Bed and one from the silty shale, $2 \mathrm{~m}$ higher within the Agardhfjellet Member. The sample from the silty shale interval produced a poor dinoflagellate assemblage with Pareodinia ceratophora, (Pareodinia sp. D. of Bjærke 1977), Chytroeisphaeridia hyalina and Nannoceratopsis pellucida. The assemblage from the ooid limestone was extremely poor and only two species were identified from this sample, $P$. ceratophora and Sentusidinium cf. verrucosum.

Sirmiodinium grossi, Pareodinia evittii and Hystrichogonyaulax cf. cladophora were recorded from a sandstone interval $28 \mathrm{~m}$ above the Brentskardhaugen Bed. Both preservation and productivity were poor.

\section{Discussion}

\section{Correlation}

The extremely poor palynomorph preservation observed in the sample from the De Geerdalen Formation (Assemblage 1) is typical for this interval (Smith 1975; Bjærke 1975; Bjærke \& Dypvik 1977). Also the abundance of cuticle fragments is characteristic of the fine-grained lithologies of the De Geerdalen Formation.

Of the 30 species recorded from Assemblage 2, 27 were also recorded from Hopen by Bjærke \& Manum (1977). Of these, ten species were restricted to the Wilhelmøya Formation, while two, Parvisaccites radiatus and Protodiploxypinus minor, were recorded from the De Geerdalen Formation only. Of the ten restricted species common to Syltoppen and Hopen, eight have also been recorded from the Wilhelmøya Formation in the Sassenfjorden area (Bjærke \& Dypvik 1977). In addition Protodiploxypinus minor was also recorded from this interval in Sassenfjorden.

Twenty-six of the thirty species recorded here at present in the Kapp Koburg Member, Wilhelmøya Formation, on Kong Karls Land, including all the species common to Hopen and Syltoppen restricted to the Wilhelmøya Formation.

Of the 30 species recorded here and the 18 species recorded from the Bjørnbogen Member, Wilhelmøya Formation at Hellwaldfjellet and Wilhelmøya, 13 species are common to both localities. Six of the ten species restricted to the Wilhelmøya on Hopen and common to Hopen and Syltoppen, are present within the Bjørnbogen Member.

Unpublished palynological data also demonstrate correlation of Assemblage 2 with assemblages obtained from the Wilhelmøya Formation at Festningen. A closely similar development seems to be present at that locality (Bäckstrøm 1980; Knarud 1980, Knorringfjellet Member). 
Table 3. Palynomorphs identified in the samples studied from the Wilhelmøya Formation.

\section{A \\ Acanthaulax senta \\ Alisporites microreticulatus \\ Annulispora folliculosa \\ Aratrisporites laevigatus \\ c \\ Camarozonosporites laevigatus \\ Camarozonosporites rudis \\ Caytonipollenites pallidus \\ Chytroeisphaeridia hyalina \\ Colpectopollis ellipsoideus Conbaculatisporites hopensis \\ Conbaculatisporites \\ mesozoicus \\ Cosmosporites elegans}

$D$

Dictyophyllidites mortonii

Duplexisporites

problematicus

E

Eucommiidites

intrareticulatus

H

Hysterichogonyaulax cf. cladophora

$N$

Nannoceratopsis pellucida

$O$

Ovalipollis ovalis

$P$

Pareodinia ceratophora

Pareodinia sp. D of Bjærke 1977

Pareodinia evittii

Pareisaccites radiatus

Protodipoloxypinus gracilis

Protodiploxypinus

microsaccus

Protodiploxypinus minor

Protodiploxypinus ornatus

S

Schizosporis sp. s. Lund 1977

Sirimiodinium grossi

Stereisporites perforatus

Stereisporites stereoides

Striatoabietites aytugii

Sentusidinium verrucosum
Drugg 1978

Reinhardt 1964

(Rogalska) de Jersey 1959

Bjærke \& Manum 1977

Schulz 1967

(Leschik) Klaus 1960

(Reissinger) Couper 1958

(Raynaud) Lentin \& Williams 1981

Visscher 1966

Bjærke \& Manum 1977

Klaus 1960

Nilsson 1958

(Couper) Dettmann 1963

Bjærke \& Manum 1977

(Deflandre) Stover \& Evitt 1978

(Deflandre) Evitt 1961

(Krutzch) Pocock \& Jansonius 1969

Gocht 1970

(Pocock) Wiggins 1975

Couper 1958

Scheuring 1970

Bjærke \& Manum 1977

Bjærke \& Manum 1977

(Pautsch) Bjærke \& Manum 1977

Warren 1973

Leschik 1955

(Potonie \& Vernity)

Thomson \& Pflug 1953

Visscher 1966

Sarjeant \& Stover 1978
Playford \& Dettmann 1965
The palynological data therefore strongly support a correlation between Assemblage 2 and assemblages previously recorded from the lower part of the Wilhelmøya Formation on Kong Karls Land, Wilhelmøya and Isfjorden.

Assemblage 3 is poorly defined, but contains Nannoceratopsis pellicida and Chytroeisphaeridia hyalina (syn. $T$. pericompsum, large variety), the two most characteristic species from the lowermost zone 1 of the Agardhfjellet Member as defined by Bjærke (1980).

\section{Age}

In previous papers dealing with the palynology of the Wilhelmøya Formation (Smith et al. 1975; Smith 1975; Bjærke \& Manum 1977; Bjærke \& Dypvik 1977), a Rhaetian age was assigned to the lower part of the formation based on comparison with NW Europe. Later studies of independently dated subsurface sections in Arctic Canada showed that these characteristic 'Rhaetian' assemblages also extend down into the Norian (Fisher 1979). Macrofossil evidence from the sequence on Hopen seems to support a Norian age for this unit (Korcinskaja 1980). The sequence covered by Assemblage 2 may therefore be of a Norian or Rhaetian age.

\section{Depositional environments}

The six metres of grey/green shales and sandstones studied from the upper part of the De Geerdalen Formation in the Bohemanflya/ Syltoppen area constitute an upwards coarsening unit that may represent prograding channel or coastal environments. The lithologically immature sediments show kerogen composition which is completely dominated by terrestrial components. Together with the sedimentological observations this indicates fluvial domination of sedimentation in an interdistributary bay environment. Minor occurrences of glauconite may suggest some marine influence.

Only the lowermost unit (equivalent to unit D, Bjærke \& Dypvik 1977) of the Wilhelmøya Formation is represented at Bohemanflya. Lithologically the formation consists of immature bioturbated claystones, which to some extent are comparable with occurrences at Festningen and Knorringfjellet (Fig. 1) (Bjærke \& Dypvik 1977; Bäckstrøm 1980; Knarud 1980). The bioturbated silty clays of the Wilhelmøya Formation are often 
carbonate cemented and display some current ripples.

The common to abundant acritarchs present (Baltisphaeridium/Michrhystridium spp. and Veryhacium spp.) within the interval covered by Assemblage 2, show that a restricted marine to lagoonal environment was established at this level. Abundant spores and pollen and dominance of wood debris show a relatively high terrestrial input. Degradation of palynomorphs and the dark wood/opaque debris may indicate oxic environments and repeated reworking of the sediments.

The geochemical Rock Eval pyrolysis, which shows a typical type III-IV, terrestrial dominated kerogen, support these conclusions. The condensed development of the Wilhelmøya Formation, occurrences of pisolites and phosphate cement in the overlying Brentskardhaugen Bed, and the coarse grained development of the somewhat younger Janusfjellet Formation, also support a marginal position of this locality.

Within correlative intervals of the Wilhelmøya Formation at Hopen, Kong Karls Land, Knorringfjellet, Wimanfjellet, and Festningen a characteristic assemblage of Rhaetogonyaulax spp. and Veryhacium spp. has been observed. This type of assemblage is not developed at Bohemanflya/Syltoppen.

The abundance of Baltisphaeridium/Michrystridium spp. and also the species of Veryhacium resemble an assemblage from the basal sandstone member of the Wilhelmøya Formation on Hopen.

Consequently the Wilhelmøya Formation was probably deposited during a weak marine transgression over an area of low relief. This resulted in periods of extremely low sediment supply and reworking of sediments by currents and wave activity, as suggested by Knarud (1980) and Mørk et al. (1982). A shallow restricted marine to lagoonal environment was established in the western and north-western part of the basin. The phosphatic Brentskardhaugen Bed is only $0.7 \mathrm{~m}$ thick at the studied locality. The content of phosphate and carbonate, together with a low siliciclastic content, shows a reduced terrestrial input. The material forming the organic aggregate has an unknown origin, but possibly represents algal debris.

The lower part of the Agardhfjellet Member, as at Festningen, is dominated by coarse, bioturbated, shallow marine silts and sandstones.

\section{Conclusion}

The Bohemanflya/Syltoppen area occupied a more marginal position than e.g. the Knorringfjellet/Marhøgda area (Bjærke \& Dypvik 1977) during the deposition of the Wilhelmøya Formation. The condensed sequence studied, of Norian to Rhaetian age, clearly represents one of the most extreme developments of the Wilhelmøya Formation. The immature sediments are characterized by a high content of terrestrial components in the organic debris.

The Bohemanflya/Syltoppen area probably also occupied a marginal position during the succeeding deposition of the Janusfjellet Formation (Callovian-Hauterivian) (Dypvik 1985; Hvoslef 1984). The presented results thus indicate that during late Triassic-Middle Triassic times the north-western extension of the Mesozoic basin in Svalbard did not extend far beyond Isfjorden.

Acknowledgements. - The comments of A. Elverhøi, J. Nagy and $\mathrm{D}$. Worsley are highly appreciated. The study was financially supported by Statoil and the Norwegian Polar Research Institute.

\section{References}

(For references to palynomorph species, see Bjærke \& Manum 1977; Bjærke 1980; Stover \& Evitt 1978.)

Bjærke, T. 1975: A palynological investigation in the upper De Geerdalen Formation - lower Wilhelmøya Formation (Rhaetic) of Hopen, Svalbard. Unpublished thesis, University of Oslo.

Bjærke, T. 1977: Mesozoic palynology of Svalbard II. Palynomorphs from the Mesozoic sequence of Kong Karls Land. Nor. Polarinst. Árbok 1976, 83-120.

Bjarke, T. 1980: Mesozoic Palynology of Svalbard IV. Toarcian dinoflagellates from Spitsbergen. Palynology 4, 57-77.

Bjærke, T. \& Dypvik, H. 1977: Sedimentological and palynological studies of upper Triassic-Lower Jurassic sediments in Sassenfjorden, Spitsbergen. Nor. Polarinst. Årbok 1976 , 131-150.

Bjarke, T. \& Manum, S. 1977: Mesozoic palynology of Svalbard - I. The Rhaetian of Hopen, with a preliminary report of the Rhaetian and Jurassic of Kong Karls Land. Nor. Polarinst. Skr. 165, 1-48.

Bäckstrøm, S. 1980: Paleontologisk og sedimentologisk undersøkelse av Brentskardhaugen-laget (Jura) på Spitsbergen. Unpublished thesis, University of Oslo.

Buchan, S. H., Challinor, A., Harland, W. B. \& Parker, J. R. 1964: The Triassic stratigraphy of Svalbard. Nor. Polarinst. Skr. $135.94 \mathrm{pp}$.

Dypvik, H. 1985: Jurassic and Cretaceous black shales of the Janusfjellet Formation, Svalbard, Norway. Sed. Geol. 41, 235-248.

Espitalié, J., Madec, M., Tissot, B. \& Leplat, P. 1977: Source rock characterization method for petroleum exploration. 
Offshore Technology Conference, Houston, Paper O.T.C. 2935.

Finnerud, E. 1982: Sammensetning, sedimentasjon og termisk omdanning av klastisk organisk materiale $\mathrm{i}$ jurassiske og krittassiske svartskifre, Svalbard. Unpublished thesis, University of Oslo.

Fisher, M. J. 1979: The Triassic palynofloral succession in the Canadian Arctic archipelago. ASS Contributions Series 5B, 83-100.

Hvoslef, S. 1984: En sedimentologisk og organisk geokjemisk undersøkelse av Janusfjellet-formasjonen pd Svalbard. Thesis, University of Oslo.

Klubov, B. A. 1965: Triassic and Jurassic deposits of Wilhelmøya. In Sokolov, B. N. (ed): Geology of Spitsbergen. Nat. Lend. Lib. Science and Techn., Boston Spa, Yorkshire, England (Eng. trans.) 1970.

Knarud, R. 1980: En sedimentologisk og diagenetisk undersøkelse av Kapp Toscana formasjonens sedimenter på Svalbard. Unpublished thesis, University of Oslo.

Korcinskaja, M. V. 1980: Early Norian fauna of the archipelago of Svalbard. Pp. 30-43 in Semevskij, D. V. (ed.): Geology of the Sedimentary Platform of the Archipelago of Sualbard. NIIGA, Leningrad.

Pcelina, T. M. 1980: New data on the Triassic/Jurassic boundary in the archipelago of Svalbard. Pp. 44-60 in Semecksi, D. V. (ed): Geology of the Sedimentary Platform and the Archipelago of Svalbard. NIIGA, Leningrad (in Russian).

Mørk, A., Knarud, R. \& Worsley D. 1982: Depositional and diagenetic environments of the Triassic and lower Jurassic succession of Svalbard. In Embry, A. F. \& Balkwill, H. R. (eds.): Arctic Geology and Geophysics. Canadian Society of Petr. Geol., Mem. 8, 371-398.

Smith, D. G. 1975: The stratigraphy of Wilhelmøya and Hellwaidfjellet. Geol. Mag. 112, 481-491.

Smith, D. G., Harland, W. B. \& Hughes N. F., 1975: Geology of Hopen, Svalbard. Geol. Mag II2, 1-112.

Stover, L. E. \& Evitt, W. R. 1978: Analyses of Pre-Pleistocene organic-walled dinoflagellates. Stanford Univ. Publ. Geol., Sci. $X V, 1-300$.

Tissot, B. P. \& Welte, D. H. 1978: Petroleum Formation and Occurrence. A New Approach to Oil and Gas Exploration. Springer-Verlag, Berlin/Heidelberg/New York. 548 pp.

Worsley, D. 1973: The Wilhelmøya Formation - a new lithostratigraphical unit from the Mesozoic of Eastern Svalbard. Nor. Polarinst. Árbok 1971, 7-16.

Worsley, D. \& Heintz, N. 1977: The stratigraphical significance of a marine vertebrate fauna of Rhaetian age, Kong Karls Land. Nor. Polarinst. Arbok 1976, 69-81. 